\title{
Shell Failed Community Engagement in Niger-Delta Region and Implications for CSR Practices: Towards Global Best Practices for Sustainable Stakeholders' Involvement
}

\author{
Dr. Adewole Adeyeye Daniel Olukayode Adekeye* \\ General and Entrepreneurial Studies, Ondo State University of Science and Technology, \\ P.M.B. 353, Okitipupa, Nigeria
}

\begin{abstract}
The study examines the experience of Shell Petroleum Development Corporation (SPDC) in Corporate Social Responsibility (CSR) practices. The study observes that the experience of SPDC is one of deep frustrations occasioned by inappropriate and ineffective stakeholders' engagement. The study also observes that aside from making host community encounter repeated deprivations, the SPDC in the Niger Delta fails to adequately involve stakeholders in its CSR agenda in ways that are acceptable. All these raised the challenge of designing best CSR practices for stakeholders' engagements to address communities that perennially suffer the negative impacts of business activities. The study concludes by attempting a template for global best practices for sustainable stakeholder engagement with hostile host communities in CSR practices in order to achieve sustainable business practices.
\end{abstract}

Keywords: CSR, Niger-Delta, Relationship Management, SPDC, Sustainability

DOI: $10.7176 /$ IAGS/93-03

Publication date: January $31^{\text {st }} 2022$

\section{Introduction}

Many literatures have consistently upheld the imperatives of Corporate Social Responsibility (CSR) practices as major enabler to sustainable business activities. In the present dispensation, businessmen can only abandon CSR agenda to their own peril. There should be symbiotic relationships between a business entity and its network of stakeholders. Research reports concur that the essential principle which guides Corporate Social Responsibility (CSR) practices is predicated on business commitment to sprawling relationship with relevant stakeholders particularly consumers, employees and host communities (Jose Milton, et al. 2010); (Andrea 2010). This relationship must be cultivated and effectively managed in order to engender sustainable activities. Feghi and Nasar (2012) affirm in their study that in management practices, Corporate Social Responsibility (CSR) has become a widely accepted approach to effective operations. In their reports on the "Role of Business in Society: An agenda for action" at Harvard University CSR and international business leaders forum, Fitz and Cormack (2006) clearly emphasized the critical role of social responsibility for successful business expeditions. There are many literatures on key features of CSR agenda, its inherent advantages and also the dangers of not implementing CSR practices.

However, there are not too many management literatures on global best CSR practices or standard model for organizations in order to maximize inherent benefits of corporate social responsibility practices. Besides, there is also lack of in-depth information as to which approach is best suited for corporate social responsibilities in terms of proper engagement of stakeholders. It is also very difficult to get materials on CSR approach for dealing with perennially hostile host communities. The frustrating experience of Shell Petroleum Development Corporation (SPDC) in the Niger Delta region of Nigeria has thrown up two major challenges along this line. The first is the need for critical re-appraisal of CSR approaches in general. The need for CSR appraisal against the backdrops of what approach is best suited in a given business circumstances. The second challenge is the prospect of global best Corporate Social Responsibility (CSR) practices for categories of business organizations as it concerns dealing with incessantly restive host communities.

The Shell Petroleum Development Company (SPDC) experience in Niger-Delta region of Nigeria has been described as a classical case study on how not to engage stakeholders in Corporate Social Responsibility practices particularly in relation to host communities. The reason for this is that Shell suffers untoward frustrations; she was driven to a point where she engaged in various pull-out threats from the Niger Delta region of Nigeria. She also experienced various directives on deadlines and orders from Nigerian government over what she needed to do. Presumably an indication that Shell, it seems, does not know or does not seem to know what she needs to do or she abdicated her responsibilities. Some explanations have been given for the unpalatable encounter experienced by Shell in the Niger Delta region. These include the use of wrong CSR approach; over reliance by Shell on in house Corporate Social Responsibility (CSR) principle which remains essentially irrelevant to the Niger Delta region; and out rightly poor method of engaging stakeholders particularly as it concerns restive host communities. 
It is the position of this study that while it may not be possible to have hard and fast principle for Corporate Social responsibility (CSR) practice in general, we agree that stakeholders' engagement, particularly dealing with restive host communities falls within the realm of relationship management which follows certain broad management principle. In this context, relationship management should be clinical, procedural and follow certain principle (Jones \& Bartlett 2009; Luu. Trong, et al 2014; Robert 2015). It is inconceivable why Shell should fail in this activity. While the study does not concern itself with why adoption of in-house CSR principles by Shell since there is no approach that is sacrosanct, the focus of the study therefore is predicated on why Shell has not effectively work in order to engender support of its critical host communities and stakeholders towards effective Corporate Social Responsibility practices. The study attempts global best practices for relationship management that should have been deployed to help in CSR practices in this context.

\section{Petroleum Exploration, Shell Petroleum Development Company (SPDC), Its Host Communities and the CSR Challenge in the Niger-Delta Region}

Shell Petroleum Development Company (SPDC) is a member of the Shell Group worldwide. The company is the operator of Nigerian Joint Venture Oil business through the Nigerian National Petroleum Corporation (NNPC). The company fully became involved after discovery of first commercial oil field in Oloibiri in the late 50's and since then, its activities in petroleum business have expanded greatly. Shell Petroleum Development Company (SPDC) participates actively in massive exploration, production and distribution of different range of petroleum products. It operates in an oil mining lease area of about 31,000 square kilometers in the Niger-Delta region of Nigeria. From its base in the Niger Delta, the company runs a network of approximately 6000 oil pipelines and flow lines, 87 flow stations, about 1000 producing wells in addition to 8 gas plants.

The Niger-Delta region is an epitome of oil wealth. It holds at least 20 billion barrel of oil reserves, while the Shell led-petroleum activities pumps about 2 million barrels of oil daily from the region. Most activities of Shell Petroleum Development Company (SPDC) are concentrated in the Niger-Delta region. The region represents the core area where exhaustive production and exploratory activities take place. Activities of Shell Petroleum Development Company (SPDC) in the Niger-Delta region according to (Chinua \& Chinedu 2001; Mbidoka 2004) include extractions, drilling, earth-moving activities, deep-sea explorations, opening of roads, bush clearing, deployment of heavy equipment, digging of borrow pits, massive construction works which include petroleum terminals. Shell constructed large terminals, including Forcados and Bonny terminals. Some of the terminals are capable of storing 13 million barrels of crude oil. There are pipeline network that criss-cross parts of the region for easy crude oil transportation. Shell is also involved in deep water drilling across the adjoining sea and water in the Niger-Delta region.

The Niger-Delta today inhabits about 31 million people of more than 40 ethnic groups with about 250 dialects (Adekeye 2014:71). The region is inhabited by Nigerian minority groups such as Itsekiris, Urhobos, Ijaws, Ilajes, Ogonis, Kalabaris', Efiks, Ikweres. Various reports have identified ways by which Shell operational activities impact negatively on its host communities (Bosen 2002; CNN 2004; Ndubuisi \& Asia 2007). First, there is serious implication for human displacements. As Shell Petroleum Development Company (SPDC) expands its exploration activities to capture new oil opportunities, it embarks on human displacements with tragic interferences and disruptions of human settlement equilibrium. Farmlands, houses and other settlements were made to be supplanted by erected oil facilities. This is one of the major causes of sporadic clashes between Niger-Delta oil producing host communities and Shell led oil companies. Second, Shell Petroleum Development Company (SPDC) often leaves in its trails, massive oil spills across land and sea in the Niger-Delta region. Oil-related chemicals spill on available surfaces across the lands and water in Shell operating areas. When this happens, the spillage kills plants and harm animals. In addition, water is polluted and the earth is de-fertilized for good planting. Third, oil companies flared about 1.7 billion standard cubic meters of gas. The negative effects of gas flaring are unimaginable. The recurring gas flares close to Niger-Delta host communities precipitate air pollution. (Ndubuisi \& Asia 2007; Aniefiok \& Udo 2013). It contributes to global warming. It also leads to many destructive air hazards. Fourth, Shell exploratory activities also pose serious health implications to its host communities in the Niger-Delta region. Apart from the fact that host communities are made to contend with polluted water and other related health risks; there is strong challenge of hydro-carbon contamination that over-hangs every inhabitant in Niger-Delta region. Finally, Shell Petroleum Development Company (SPDC) activities promote and exacerbate poverty in the Niger-Delta region. Encroachments on farmlands and water ways due to oil spillage and massive water pollution have denied Niger Delta host communities major sources of livelihood. Oil spills make farm lands unfit for cultivation, available plants are easily exterminated while fishes are poisoned to death. By implications, Shell Petroleum Development Company (SPDC) exploratory activities have engendered and perpetuated personal and community poverty across NigerDelta Region of Nigeria. Against the backdrop of these problems with host communities in the Niger Delta region, there is fundamental challenge of instituting responsive Corporate Social Responsibility (CSR) practices if the business of Shell is to be sustained in Niger-Delta region. 


\section{Shell CSR Activities in Niger-Delta Region and Failure to Properly Engage Host Communities}

Available evidences point to the fact that Shell Petroleum Development Company (SPDC) is guided by two principles in its corporate social responsibility (CRS) activities. The first principle is the Shell General Business Principles (SGBP). The kernel of Shell General Business Principles (SGBP) upholds commitment to the following established principles in all activities worldwide including the Niger Delta region:

- Emphasis on compliance

- Growing concern about security Post - 9/11

- Emphasis on social performance and with communities.

- Shell enterprise first values and behaviors

- Development of sustainable principles

- Clarity on treatment of facilitation payments

The other aspect of Shell Petroleum Development Company (SPDC) corporate social responsibility agenda is Issue Management Initiatives. The issue management initiative is aimed at dealing with specific corporate social responsibility (CSR) situation as they unfold.

Shell Petroleum Development Company claims to fully engage its host community by working with local organisations and ensure that benefits of its resources are fed to communities and businesses. A critical appraisal of Shell Petroleum Development Company (SPDC) corporate social responsibility (CSR) activities clearly indicates that it lacked the depth and seriousness to tackle the critical challenge which confronts host communities as a result of Shell exploratory activities.

Shell corporate social responsibility (CSR) activities lacked the finesse to pro-actively appreciate the critical nature of the problems they perpetrated on their host communities. It also did not seem to gather enough muscle to address the challenge created for the host communities head on. Instead, Shell seems to focus only on trivialities emanating from her established corporate principles which they could not properly align with development exigencies in the Niger Delta region and the problems it poses for her sustainability. Little wonder why the high sounding Shell General Business Principles (SPDC) did not bring about substantial physical and environmental remediation to host communities in the Niger-Delta. Also, the issue management strategy is rather unstructured in conception. It is sporadic both in designs and applications. Hence, most of the various projects embarked upon by Shell failed to placate host communities because the project did not engender their genuine involvement. If the results of devastating effects of oil activities is anything to go by, according to (Watts, 2005) there is no way Shell could have successfully captured the needs of stakeholders unless the host communities in Niger Delta region are practically involved both in CSR project conception and applications. The resultant dissatisfaction by host communities eventually led to intense restlessness.

In strict CSR stakeholders' involvement sense, there is no reason why Shell Petroleum Development Company should not have adopted Niger-Delta Region as Shell Corporate Region. This can be achieved by developing cordial relationship through stakeholder involvement in Shell activities. It also entails sensitivity, prompt and quick response to all shades of interest, from the onset in a manner that distinguishes every stakeholder particularly host communities as part and parcel of Shell corporate family. After all, the Niger-Delta region is the heartland of Shell mainstream activities. Unfortunately, Shell was only acting the brief of archaic Milton Friedman approach to corporate social responsibility which focuses on maximizing shareholders profit at the expense of other stakeholders. This approach is no longer fashionable in the present circumstance. Corporate stakeholders in the present era are very much aware of their rights and interests. Corporate organizations must acknowledge stakeholders interests and also carry them along for sustainable business practices.

\section{The Imperatives of Stakeholders' Involvement for Sustainable CSR Practices}

A key feature of effective and sustainable CSR is the need to make stakeholders' interests paramount in corporate management (Clark \& Bahson 2012; Bahaudin 2013). Stakeholders' interests should be seen as paramount from the very day of business conception. Therefore to deliver sustainable CSR initiative, it means that every stakeholder's interest must be incorporated and accommodated through getting them involved (Shillington 2008). This entails voluntary integration of social, education, environmental, and other related concerns of stakeholders into the thinking and activities of business operations. Stakeholders' interest must be integrated into each phase of business activities (Fox 2007; Porter \& Kranner 2011). This is the heart of effective and sustainable CSR initiative.

Getting stakeholders involved for sustainable CSR practice should be a one step program. It should be a corporate activity that lasts through-out her entire life span. Sustainable and effective stakeholders' involvements through CSR initiatives are not piecemeal. They are not sporadic or discretionary as it has been the case with Shell. And it also goes beyond issues management. While issues management merely scratches the surface, stakeholders' involvement focuses on joint initiative to deal with problems in a sustainable way. It is an approach in which both parties (company and the concerned stakeholders) are made to jointly diagnose stakeholders' problems, provide acceptable solutions and collectively work to actualize solutions.. 


\section{A Model of Stakeholders' CSR Engagement for Sustainable Business Practices}

To achieve sustainability through stakeholders' involvement, companies must internalize concerns for stakeholders' interest into operational methods. Stakeholders' involvement for sustainable CSR practice is a lifelong corporate affair. It is a process that should be built and internalized by corporate organizations into operational procedures. This can be achieved through the following stepladder.

\section{Step 1: Appraisals of Corporate Critical Stakeholders}

Every corporate organization has network of stakeholders. These stakeholders are individuals, groups, institutions and other related parties who are affected one way or the other by activities of corporate organizations. These stakeholders have certain expectations from corporate organizations. It is the responsibility of corporate organization to successfully identify and manage such expectations. An important step in the life of success-driven organizations is to properly identify and understand the peculiarities of its network of stakeholders'. The stakeholders of an average corporate organization and their traditional expectations are as follows:

Workers:-

- $\quad$ Payment of fair wages

- Provision of safe working environment

- Opportunities for workers representation

- Ethics and fairness in the workplace

- Equal and available opportunities for training \& capacity building

- Improved workplace environment and performance of employees

- Adequate opportunities for promotion

- Cordial management/employee relationship

- Right to be treated fairly

Competitors:-

- Fair competition

- $\quad$ Use of defensive instead of destructive competitive strategy

- Promotion of fair and favorable business climate

- Best market practices initiatives

- $\quad$ Avoidance of Price war

- $\quad$ Level playing field

- $\quad$ Free entry and exit

Consumers:-

- Quality services at reasonable prices

- Product responsibility

- Avoid unethical practices

- Adequate consumer information on products

- Lack of product misrepresentation

- Consumer protection

- Respect for consumer's right of choice

- No activities that undermine consumer

Shareholders:-

- Disseminate timely information on business state of affairs

- Safe treatment of all categories of shareholders' investment

- Wealth Protection.

- Corporate governance

- Fair treatment of all categories of shareholders.

- Ensure adequate returns on capital invested.

Environment:-

- Resource conservation.

- Maintenance of human natural ecosystem.

- Address climate change

- Prevention of harmful discharge of industrial wastes.

- Minimization of air, land and water pollution.

- Keeping the environment safe and clean.

Government:-

- Payments of relevant taxes/levies.

- Supports government activities especially those of legitimate government.

- Undertakes research and development to promote growth in society. 
- Contributes towards broad government development program.

- $\quad$ Provides basic needs of the society.

- Sponsors events and other complimentary development activities.

Host Communities:-

- Embark on community impact assessment programs

- Confront societal challenges

- Contribute towards better life of the community

- Assists in providing economic, social and physical infrastructures.

- Mitigate negative effects of company activities on the community.

- Community investments

- $\quad$ Provide welfare schemes for the community

- Participate in Community Development Association (CDA) program

International Business Environment:-

- Support for the emerging global business order.

- $\quad$ Comply with global business rules, statutes and standards.

- Demonstrate CSR global best practices

The above summary of stakeholders' expectations is not exhaustive. It is therefore the duty of Corporate Social Responsibility (CSR) managers to gauge expectations from time to time. Managers should also never make the mistake of believing that one stakeholder is more important than the other. This will amount to a big error. Instead, the expectations of each stakeholder must be understood against the backdrop of their individual uniqueness.

Step 2: Open a CSR deal with network of stakeholders.

After identifying all the critical corporate stakeholders and their corresponding expectations, corporate managers should strike appropriate deal with stakeholders. Avenue should be created for regular rapport between the company and its stakeholders. In other words, there is preponderance of a formal arrangement where regular meetings are held. The aim is to discuss issues of mutual interests. It is important for companies to take practical steps by initiating exchange of ideas that border on stakeholders' interests and courting friendship. Companies should be able to establish rapport with stakeholders such that stakeholders would have confidence that a mutually beneficial relationship is in the offing. This can be achieved through direct invitations of stakeholders by regular correspondences for discussions and articulations of issues of mutual interests. Stakeholders should be involved in the articulation of both the short, medium and long term expectations. They should also be involved in the analysis of those expectations. During the process of such discussions, certain questions would be asked that require joint answers. Some of the questions may include: What are the broad objectives of company activities? How is company operation going to affect each of the stakeholders? When these questions are jointly raised, companies would be able to properly incorporate stakeholder's concerns into corporate actionplan from onset.

Step 3: Make Deal with Stakeholders towards finding solution to Specific Problems.

After they (Company and Stakeholders) have jointly determine the needs and concerns of stakeholders, the next step is for company to create avenue for both parties to collectively strike deal on how the problems can be solved. This is a crucial stage in CSR stakeholders' involvement practices. It is also a stage for frank discussions by both parties. Various articulations must be frankly and honestly discussed by both parties. Discussions must be sincere, credible and down to earth. Discussions should cover how positive impacts of corporate activities can be further increased while it should also focus on available remedies for mitigating negative impacts? In essence, the aim is to ensure that stakeholders are practically involved in the analysis of stakeholders' expectations and how to satisfy those expectations. At this stage, available options, policies and actions required for dealing with stakeholders' interests must be clearly spelt-out. At the end of the exercise, both parties must put themselves in a situation where they both agree to share the journey together. And as both parties agree eventually, the agreement must never be based on winner-loser relationship. Rather, it must encapsulate a win-win rapport so that all parties can remain satisfied with one another.

\section{Step 4: CSR Initiative Program Implementation}

This stage is also for CSR program implementation. Of course, most of the responsibility at this stage rests heavily on corporate organizations. At this stage, it behooves on corporate organizations to ensure that every item that were earlier agreed upon are fully implemented to the delight of both parties. Corporate organizations must rigidly follow plans that were jointly agreed by both the stakeholders and the company. Stakeholders' issues that have been agreed to in terms of problems and how to solve those problems must be religiously prosecuted. When companies do this, there is no way they can be accused of insensitivity and renege on agreed 
action plans. This is the very essence of Stakeholders' involvement in sustainable CSR practices.

\section{Step 5: CSR Program Periodic, Review and Monitoring}

This is a very critical stage. As programs are being implemented, there should be periodic monitoring and review meetings. At such meetings, stakeholders would need to be invited; opinions sought about CSR initiatives as it concerns stakeholders. Areas of successes should be noted for possible scale up. Where there are apparent laxities suggestions are developed for incorporation into subsequent action-plans. Any suggestions that are jointly agreed upon at this stage must be integrated for immediate implementations.

\section{Conclusion}

Shell in the Niger Delta region of Nigeria has invested billions of naira in the region, yet the host communities and other stakeholders do not feel they have done something! Rather, the company has continued to experience damning frustrations that threatens business existence. It is possible for them to spend less of the amount and achieve fantastic result particularly if they strike a sincere deal with their stakeholders in the context of emerging stakeholders' engagement model for sustainable CSR practices. Clearly the Shell experience points to the ineffectiveness of issues management approach to CSR practices which is very common to most companies. Issues management is too simplistic and ineffective. It is not applicable in the context of critical stakeholders' breaches like the Niger-Delta scenario. The issue based management approach may have been successful in developed countries where crisis is less and awareness is higher. The same cannot be said of developing countries particularly with the Niger Delta scenario. Quintessentially, we have been able to underscore the fact that stakeholders' strategic involvement is the best form of maximizing benefits of CSR activities by corporate organizations. We have also exemplified the step by step technical and professional model stakeholders' involvement towards effective CSR practices. One thing is also very sure, expectations in stakeholders relation is never a one-way thing. When corporate organizations lived up to stakeholders' expectations, there are ways in which organizations reap the benefits of meeting stakeholders' expectations. One of the ways is that they reap the benefits of adequate supports from stakeholders. Stakeholders cherish and respect their involvements. When corporate organization involves stakeholders, the stakeholders are on the long run bound by commitment. Instead of taking up arms against such corporate organizations as it is often the case at the moment, they rather will defend the business' cause, no matter what it takes, after all their interest has been duly taken care of.

\section{References}

Adekeye, Daniel. 2014. Emerging Identity, Social Values and the New Social Order in the Niger Delta. AFRICANA 7(1):61-95.

Asolo, Adeyeye. 2005. "New Global Business Moral Order and Business Activities in Developing Countries: The Nigerian Experience". In International Corporate Responsibility Series, edited by Hooke, J. and Madsen, P. 2:285-302.

Asolo, Adeyeye. 2006. "WTO, Multilateral Trade Agreements in Africa and the Challenge of Establishing United Nation Global Regulatory Agency". A Paper Presented at International Conference on WTO Trade Agreements and Impact on Poverty and Inequality in Developing Countries. Ben-Gurion University of the Negev. Beer-Sheba Israel March 1-2.

Asolo, Adeyeye. 2006. "Malaysian SME's, Global Opportunities and the Challenge of Global Business Moral Order”. In Small and Medium Enterprises (SME's): Malaysian \& Global Perspectives, edited by Ndubisi. N. O. and N.O. Saleh. Malaysia: Pearson/Prentice Hall. 319-329.

Asolo, Adeyeye. 2007. Corporate Social Responsibility, Self-Regulation and the Problems of Unethical Practices in Africa: A Case for the Establishment of United Nations Global Business regulatory Agency. Controversies in International Corporate Responsibility series. 3:69 - 81.

Andrea, Moffat. 2010. The 21 st Century Corporations: The CERES Roadmap for Sustainability. http://ww.calpers.ca.gov/docs/governance/2010/ceres-roadmap-for-sustainbility.pdf (accessed 11 June 2015).

Aniefiok, E. Ite and Udo, J.I. 2013. Gas Flaring and Venting Associated with Petroleum Exploration in the Niger Delta Region. America Journal of Environmental Protection 1(4):70 - 77.

Bosen and Li, Huailin. July 12, 2008. Vandalism rampant in Niger-Delta Region of Nigeria. http://news.xinhuanet.com/english/2008-07/12/content_8535454.htm. (accessed 6 July 2010).

Bowie, N. 1991. New Direction in Corporate Social Responsibility. Business Horizons 34(4):56-65.

Bahaudin, G.M. and Frank, J.C. 2013. Corporate Social Responsibility and Sustainability Model for Global Firms. Journal of Leadership, Accountability and Ethics. 10 (1):58-75.

Chinedu, I. and Chinua, A. March 8, 2001. Niger Delta, Nigeria: Issues, Challenge and Opportunities For Equitable Development. Nigeria World feature. http://nigeriaworld.com/articles/2000-2001/niger-delta.html. (accessed 15 July 2016). 
Clarkson, M.B.E 1995. A Stakeholder Framework for Analyzing and Evaluating Corporate Social Performance. Academy of Management Review. 20:92-117.

CNN. 2004. Shell Admits Blame in Nigeria. http://edition.cnn.com/2004/WORLD/africa/06/11/nigeria.shell/. (accessed 12 March 2017).

Clark, W.H. and Babson, E.K. 2012. Business Organizations: When Business Purpose Disappears: How Benefit Corporations are Redefining the Purpose of Organization. Williams Mitchel Law Review. 38:817 - 844.

David, Henderson. 2004. The Role of Business in the Modern World: Progress, Pressures and Prospects for the Market Economy. Washington: Competitive Enterprises Institute.

Davis, K. 1973. The Case For and Against Business Assumption of Social Responsibilities. Academy Management Journal of. 16:312 - 322 .

Eusebius, Mbidoka. May 19, 2004. The Ethical Evaluation of Shell BP in Nigeria via-a-vis the Ogoni Case. Nigeria World. http://nigeriaworld.com/articles/2004/may/191.html. (accessed 15 July 2016).

Evan, M. Freeman. 1993. "A Stakeholder Theory of the Modern Corporation" In An Introduction to business Ethics, edited by G.D. Chryssides and J.H. Kaler. Chapmans Hall.

Freeman, E. 1984. Strategic Management: A Stakeholder Approach. Boston: Pitmans.

Fitz, Gerald N. and Cormack, M. 2006. The Role of Business in Society: An Agenda for Action. Prince of Wales International Leaders Forum. 1 - 35.

Fox, Adrienne. 2007. Corporate Social Responsibility. Pay off HR Magazine. 43 - 47.

Godwon, Emakpe. April 3, 2008. Nigeria: Gas flowing-Niger-Delta Youth Sue Shell, Total, Exxon Mobil, Chevron others, Leadership Newspapers, Abuja, Nigeria.

Gulbaridsen, L.H. and Moe, A. 2005. Oil Company CSR Collaboration in New Petrol- States. Journal of Corporate Citizenship. 20:52-64.

Jones, T.M. 1980. Corporate Social Responsibility Revisited Redefined. California Management Review. 22:5967.

Jones, K. and Bartlett, J.L. 2009. The Strategic Value of Corporate Social Responsibility: A relationship management framework for public relation practices PRISON $6(1)$. http://.praxis.massey.ac.NZ/prison_onlinejournal html (accessed 3 March 2012).

Jose Milton, Lilian Soares, Carla P.G. and Francisca, F. 2010. Strategic Corporate Social Responsibility. Brazilian Administration Review. 17(3) on-line version ISSN 1807 - 7692 (accessed 16 August 2013).

Kaler, J. 1999. Understanding Participation. Journal of Business Ethics. 21:125-135.

Luu Trong Tuan and Luu Thi Bich Ngoc. 2014. CSR-based model of clinical governance. International Journal Pharmaceutical and Healthcare Marketing. 8(1):62 - 97.

Marsoden, C. and Andriof, J. 1998. Toward an Understanding of Corporate Citizenship and How to Influence. Citizenship Studies. 2:329-352.

Micheal, Jensen. 2001. Value Maximization, Stakeholder's Theory and the Corporate Objective Formulation. Journal of Applied Corporate Finance. Fall 8 - 21.

Nik, Ogbuile. October, 2008. In defense of Shell. The Guardian. Lagos, Nigeria.

Ndubuisi, O.L \& Aisha, I.O. 2007. Environment Pollution in Oil producing area of the Niger Delta Basin, Nigeria. Empirical Assessment of Trends and Peoples' Perception. Environment Research Journal. 1:18 26.

Papineau, D. and Kiely, M. 1996. Participation Evaluation in a Community Organization: Fostering Stakeholder Empowerment and Utilization. Evaluation and Programme Planning. 19:79-93.

Prieston, L.E., Pokhl, J.E. and Rosen, H.D. 2004. "Implementing CSR in China through Stakeholders Involvement". In International Corporate Responsibility, International Management Series, edited by Hooker, T. and P. Madsen. Vol 3. Carnegie Mellon University Press.

Porter, M.E. and Kranner, M.R. 2011. Creating Shored Value-How to Reinvent Capitalism and Unleash a New Wave of Innovation and growth. Harvard Business Review. 89(1):63 - 77.

Robert Lee Simmon. 2015. The relationship between Customer Relationship Management Usage, Customer Satisfaction and Revenue. http://www.scholarworks.waldenu.edu/dissertations (accessed 12 October 2016).

Shillington, Patty. June 16, 2008. Investors do well doing good. The Miami Herald. Business Monday, p. 13.

Watts, M.J. 2005. Righteous Oil? Human Rights, The oil complex and Corporate Social Responsibility. Annual Review of Environment Resources. 30:373 - 407.

Windsor, D. 2001. The future of Corporate Social Responsibility. The International Journal of Organizational Analysis. 9:225-256. 